\title{
Testicular morphology and seminal fluid parameters of adult Wistar rats following honey administration
}

\author{
Eniola R Kadir ${ }^{{ }^{\star}}$, Lekan S Ojulari ${ }^{2}$, Abdulmumin Ibrahim $^{1}$, Oluwole J Ekundayo ${ }^{1}$, \\ Rukayat Jaji-Sulaimon ${ }^{1}$, Hidaayah 0 Jimoh-Abdulghaffaar ${ }^{2}$ \\ ${ }^{1}$ Department of Anatomy, ${ }^{2}$ Department of Physiology, Faculty of Basic Medical Sciences, University of Ilorin, Ilorin, Nigeria \\ *For correspondence: Email: ennyshittabey@yahoo.com; Tel: +234-8023550366
}

\begin{abstract}
Purpose: Honey has a long history of use in the traditional medical systems This objective of this study was to find out the effects of honey on quality and quantity of sperm and testicular microstructure when compared to fertility boosting drug and controls.

Methods: A total number of thirty (30) matured male Wistar rats that were sexually active weighing 200 - $280 \mathrm{~g}$ were used for this study. The animals were grouped into five as A - E. Group A was the control; Group $B$ (standard group) was the standard group that received $0.3 \mathrm{ml}$ of follicle stimulating hormone (FSH) drug for 6 days; groups $C, D$ and $E$ received $1 \mathrm{ml}, 2 \mathrm{ml}$, and $2.5 \mathrm{ml}$ of honey daily for 21 days respectively. After 21 days of administration, the testes were removed for analysis of the sperm parameters and the histology.

Results: Honey significantly improved the sperm quality and spermatogenesis rate (denser seminiferous tubule lumen) of exposed animals compared to control animals, but most improvement was seen in the standard group that received $0.3 \mathrm{ml} \mathrm{FSH}$. Also no sign of degeneration or cellular loss was observable in the testicular histo-architecture of experimental animals.

Conclusion: This research showed that honey possesses some fertility boosting properties in exposed animals compared to controls and honey is not associated with increased sperm abnormalities.
\end{abstract}

Keywords: Honey, Fertility booster, Spermatozoa, Ologospermia

\begin{abstract}
This is an Open Access article that uses a funding model which does not charge readers or their institutions for access and distributed under the terms of the Creative Commons Attribution License (http://creativecommons.org/licenses/by/4.0) and the Budapest Open Access Initiative (http://www.budapestopenaccessinitiative.org/read), which permit unrestricted use, distribution, and reproduction in any medium, provided the original work is properly credited.
\end{abstract}

Tropical Journal of Pharmaceutical Research is indexed by Science Citation Index (SciSearch), Scopus, International Pharmaceutical Abstract, Chemical Abstracts, Embase, Index Copernicus, EBSCO, African Index Medicus, JournalSeek, Journal Citation Reports/Science Edition, Directory of Open Access Journals (DOAJ), African Journal Online, Bioline International, Open-J-Gate and Pharmacy Abstracts

\section{INTRODUCTION}

Fertility in males is largely dependent on adequate production of healthy spermatozoa by the testes, these days many men have resolved to the use of alternative substances (like fruits, herbs, honey etc.) for fertility boost [1]. It has been recorded that approximately $70 \%$ of men worldwide use alternative medicinal substances that are cheap and readily available to increase their sperm content [1]. The World health organization [2] endorsed honey and other sperm boosting supplement as being safe for usage [3]. Studies have shown that honey increased spermatogenesis in rats i.e. sperm boosting properties [4]. A report from Malawi suggested that long term administration of honey had no negative effect on the histopathology of Wistar rats' testis [5], and Igbokwe et al [6] found increase in sperm parameters in honey treated 
animals, while a contrary result was obtained by Dare et al [3] who reported reduced motility and increased percentage of dead and abnormal spermatozoa in honey treated animals.

Bees produce this sweet food (honey) by using nectars from flowers. Honey has a long history of use in the traditional medical systems [7]. It has a density of about $1.36 \mathrm{~kg} /$ litre (i.e. $36 \%$ denser than water). The major active constituent which has been found to have strong fertility effect is the Chrysin [8] which is a bioflavonoid compound. This compound is in high quantity in honey and propolis. Chrysin is also known for its testosterone boosting activity Dhawan et al [9]. It also inhibits the conversion of testosterone to estrogen [10]. It appears to be poorly absorbed and also sufficiently metabolized, hence low levels are found in testes and blood. These levels are insufficient to exert the beneficial effects of testosterone boosting Kohut et al [11].

Chrysin, like most bioflavonoids, is poorly bioavailable in its isolated form. This makes its actual use to be decreased [12]. Its bioavailability is thought to be due to its extensive metabolism and intestinal transportation.

Chrysin, similar to most bioflavonoids, is poorly bioavailable in its isolated form. This makes its actual use to be decreased [12]. Its poor bioavailability is thought to be due to its extensive metabolism and intestinal transportation. Organs containing the P450 system such as the liver, easily conjugates chrysin into chrysin glucuronidase and chrysin sulphate, which are its metabolites though may not be bioactive. Glucuronidation rates are increased in the intestinal cells via induction of UGT1A1 expression by chrysin, which further supports its low bioactive levels [12]. Therefore, this work aims to determine the effect of honey on seminal fluid parameters and morphometry of the seminiferous tubules.

\section{METHODS}

Thirty (30) male Wistar rats weighing between $200 \mathrm{~g}-280 \mathrm{~g}$ were used for the study. They were kept in the animal house of the College of Health Sciences, University of llorin under normal atmospheric condition of $25{ }^{\circ} \mathrm{C}$. The animals were divided into five (5) groups randomly. Each group consist of six (6) rats. Group A was the control; group B was administered $0.3 \mathrm{ml}$ of follicle stimulating hormone drug for 6 days [13] (standard group), group $\mathrm{C}, \mathrm{D}$ and $\mathrm{E}$ received $1 \mathrm{ml}, 2 \mathrm{ml}$, and $2.5 \mathrm{ml}$ of honey daily for 21 days respectively (increasing quantity of administered honey) [10]

\section{Semen analysis}

\section{Sample collection}

The Wistar rats were sacrificed after the experiment. They were administered inhalation anaesthetic (ether), then sacrificed by cervical dislocation.

Open castration method was used for orchidectomy via a midline scrotal incision. Then the testicles were gently milked out through the incision site. The testicles were exposed by incising the tunica vaginalis, followed by exposure, ligation and incision of the spermatic cord. The cauda epididymis was then identified, from which the semen samples were collected. Saba et al [14] and Oyeyemi and Ubiogoro [15] described a similar method of semen collection. The semen samples were then analysed immediately.

\section{Sperm motility and count assay}

A drop of semen was placed on a glass slide to assess sperm motility. $2.9 \%$ sodium citrate was added. This was covered with a glass slip, then the microscopic fields were viewed under the light microscope to determine the motile and non-motile spermatozoa. This method was as described by Zemjanis [16].

Sperm count was with the use of a hemocytometer. The cauda epididymis was minced in normal saline, then filtered and an aliquot of 10ul was placed on the hemocytometer. The improved Neubauer chamber (Deep 1/10m, LABART, Munich, Germany) was used for the count, under a light microscope [17].

\section{Sperm morphology and viability assay}

Four hundred (400) spermatozoa count were used to determine this. The semen was placed on the slide, then Wells and Awa stains (which consist of $0.2 \mathrm{~g}$ eosin and $0.6 \mathrm{~g}$ fast green dissolved in distilled water and ethanol in ratio 2:1) was added, as documented by Wells and Awa [18]; Isaac and Ebenezer [19]. This was then viewed under the microscope

In determining the viability, a drop of semen was placed on the slide, then addition of a drop of eosin-nigrosin stain (which is $1 \%$ eosin with $5 \%$ nigrosin in $3 \%$ sodium citrate solution). This was mixed well then air dried. It was then observed under the microscope for the live and dead spermatozoa cells, which were counted as 
described by Wells and Awa [18] and Isaac and Ebenezer [19].

\section{Statistical analysis}

Data collected were analyzed using one-way analysis of variance (ANOVA) followed by Tukey's multiple comparison test with the aid of SPSS (V20; USA). The data were presented as means \pm SEM (standard error of mean). $P \leq 0.05$ was considered statistically significant.

\section{RESULTS}

\section{Histology of the testes}

The proliferation of spermatogonic series (SG) into matured spermatozoa in the seminiferous tubular lumen (L) was observed in the control rats (Figure 1). There was an improvement in the proliferation rate of the spermatogenic series (SG) in the FSH treated rats (Figure 2), shown by the presence of abundant spermatozoa in the seminiferous tubular lumen (L), i.e., a dense lumen. The basement membrane was also intact and there were Leydig cells present in the interstitium (I).

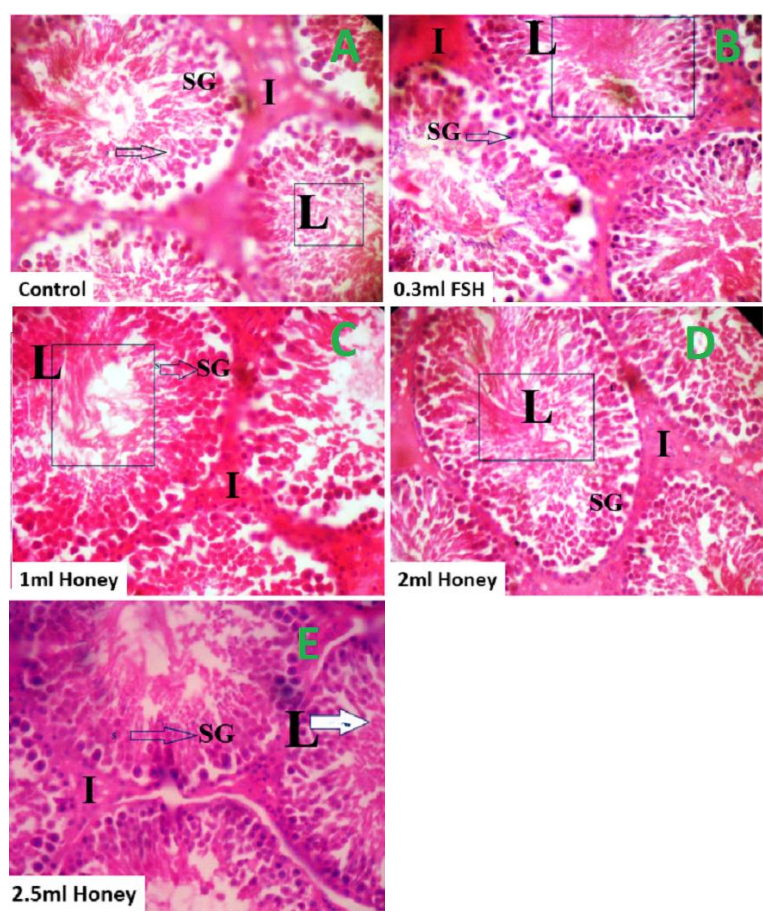

Figure 1: Phoomicrograph showing sections of the seminiferous tubules of control rats, L-lumen $(A)$, rats treated with $0.3 \mathrm{ml} \mathrm{FSH}$, L-densely packed lumen $(B)$, rats treated with $1 \mathrm{ml}$ honey, L-densely packed lumen (C), rats treated with $2 \mathrm{ml}$ honey, L-densely packed lumen (D) and rats treated with $2.5 \mathrm{ml}$ honey, L-lumen. Stain H\&E; X100. SG - spermatogonia cells, Iintestinal space
Additional increases in the doses of honey in the honey treated groups (III, IV and V) showed progressive proliferation of spermatogonic series (SG) into matured spermatozoa in the seminiferous tubular lumen (L) with intact basement membrane and interstitial space (I). This is shown in Figure 1 (C-E).

\section{Semen analysis}

Sperm Count: The sperm count was significantly increased $(p<0.001)$ in the FSH treated group $\left(254.6 \pm 4.07 \times 10^{4} / \mathrm{mL}\right)$ when compared to control $\left(142.2 \pm 21.25 \times 10^{4} / \mathrm{mL}\right)$ (Table 1). A dose dependent significant increase $(p<0.01)$ was also recorded in the honey treated groups (group III$190.90 \pm 9.41 \times 10^{4} / \mathrm{mL}$, group IV- $204.30 \pm 4.05 \times$ $10^{4} / \mathrm{mL}$ and group $\mathrm{V}-205.33 \pm 1.48 \times 10^{4} / \mathrm{mL}$ ).

Sperm Motility (\%): The sperm motility was significantly increased in all experimental groups when compared to control $(66.30 \pm 0.99 \%)$, with the highest increase recorded in the FSH treated group $(84.76 \pm 0.74 \% p<0.001)$. Sperm motility was $(70.94 \pm 0.92 \% \quad p<0.05) \quad(70.53 \pm 1.66 \%$ $p<0.05)$ and $(74.80 \pm 0.53 \% p<0.05)$ in groups III, IV and $\mathrm{V}$, respectively (Table 1 ).

Sperm Morphology (\%): There was significant increase in group II $(79.02 \pm 0.28 \% p<0.01)$ and group V $(78.57 \pm 2.67 \% p<0.05)$ when compared to control (72.32 $\pm 2.01 \%)$. Groups III and IV showed insignificant increases $(p>0.05)$ when compared to control (Table 1).

Life/Death Ratio (\%): The life/death ratio was increased in all experimental groups (II$87.24 \pm 0.86 \%$, III- $79.18 \pm 1.28 \%$, IV- $75.38 \pm 2.89$ and $\mathrm{V}$ - $80.59 \pm 0.89$ ) when compared to control $(81.04 \pm 1.29 \%)$, but was only significant ( $p$ $<0.05$ ) in the $\mathrm{FSH}$ treated group (Table 1).

\section{DISCUSSION}

The histological evaluation of the actions of honey on the microstructure of the testes revealed less dense packing of spermatogenic cells in control compared to the FSH and honey treated groups. Also, the lumen of control was less densely filled with seminiferous tubular lumen with spermatozoa compared to FSH and honey treated groups. The increase in the abundance of spermatozoa in the lumen is dose dependent among the groups that received varying doses of honey as most spermatozoa i.e. denser lumen, was seen in animals that received $2 \mathrm{ml}$ and $2.5 \mathrm{ml}$ Honey, which is similar to findings by Nworah et al [5]. 
Table 1: Semen profile

\begin{tabular}{|c|c|c|c|c|}
\hline Group & $\begin{array}{c}\text { Sperm count } \\
\text { (Total No. } \\
\left.\times 10^{4}\right)\end{array}$ & $\begin{array}{c}\text { Sperm } \\
\text { motility } \\
(\%)\end{array}$ & $\begin{array}{c}\text { Sperm } \\
\text { morphology } \\
(\%)\end{array}$ & $\begin{array}{l}\text { Life/death } \\
\text { ratio (\%) }\end{array}$ \\
\hline Control & $142.20 \pm 21.25$ & $66.30 \pm 0.99$ & $72.32 \pm 2.01$ & $81.04 \pm 1.29$ \\
\hline $0.3 \mathrm{ml} \mathrm{FSH}$ & $254.60 \pm 4.07^{\star \star *}$ & $84.76 \pm 0.74^{\star \star *}$ & $79.02 \pm 0.28^{* *}$ & $87.24 \pm 0.86^{\star *}$ \\
\hline $1 \mathrm{ml}$ honey & $190.90 \pm 9.41^{* *}$ & $70.94 \pm 0.92^{*}$ & $74.74 \pm 1.55$ & $79.18 \pm 1.28$ \\
\hline 2ml honey & $204.33 \pm 4.05^{\star \star \star}$ & $70.53 \pm 1.66^{*}$ & $75.67 \pm 2.48$ & $75.37 \pm 2.89$ \\
\hline $2.5 \mathrm{ml}$ honey & $205.33 \pm 1.48^{\star * *}$ & $74.80 \pm 0.53^{\star *}$ & $78.57 \pm 2.67^{*}$ & $80.57 \pm 0.87$ \\
\hline
\end{tabular}

Sperm count, percentage sperm motility, morphology and life death ratio of animals treated FSH and varying doses of honey. Data represented as mean \pm SEM. * $(P \leq 0.05),{ }^{* *}(P \leq 0.01),{ }^{* * *}(p \leq 0.001)$

Previous studies revealed that honey of appropriate dose might enhance the third stage of spermatogenesis in rats [20] Yousef and Salama [21] observed a similar finding of honey acting as a physiologic modulator for spermatogenic cell proliferation, which influence the cell cycle of the seminiferous epithelium thus, increasing spermatogenesis.

Likewise, follicle stimulating hormone has been tested and confirmed to cause an increase in spermatogenesis [22]

The characteristics measured by semen analysis are some of the factors in semen quality that determine the viability of sperm [23]. There was a significant dose-dependent increase in the percentage sperm motility and sperm count following treatment with honey. This corresponds to findings by lgbokwe et al [6], who reported the potency of honey as a fertility boosting agent and Salman et al [24], whose findings were also suggestive of the beneficial effects of honey on sperm count.

Honey contains several metals, amongst which is zinc [25]. These findings are suggestive of zinc accumulating in the testis during early spermatogenesis. Therefore, it may be important in DNA synthesis and regulation of spematogonial proliferation [26].

\section{CONCLUSION}

Though there is not enough established data concerning the medicinal use of honey in treating human male infertility currently, this study revealed that honey is potentially useful as a fertility boosting agent by improving on the qualitative and quantitative parameters of spermatogenesis in a dose dependent manner.

\section{DECLARATIONS}

\section{Acknowledgement}

The authors would like to acknowledge the staff of the Department of Anatomy, University of
Ilorin, for helping with tissue preparation. We also want to appreciate Mrs Akanbi-Ola for her various contributions during the course of the study and preparation of the manuscripts.

\section{Conflict of Interest}

No conflict of interest associated with this work.

\section{Contribution of Authors}

The authors declare that this work was done by the authors named in this article and all liabilities pertaining to claims relating to the content of this article will be borne by them.

\section{REFERENCES}

1. Harlev A, Agarwal A, Gunes SO, Shetty A, Simon du Plessis S. Smoking and Male Infertility: An EvidenceBased Review. World J Mens Health 2015; 33 (3) 143160.

2. World Health Organization. WHO Laboratory Manual for Examination of Human Semen and Semen-Cervical Mucus Interaction, Ed 4, Cambridge: The Press Syndicate of the University of Cambridge, 2009.

3. Dare WN, Igbigbi PS, Avwioro OG. The Effect of Chronic Honey Intake On Sperm Parameters and Fertility Potential in Adult Male Wistar Rats. World App Sci Jour 2013; 22 (5) 657-661.

4. Abdul-Ghani AS, Dabdoub N, Muhammad R, AbdulGhani R, Qazzaz, M. Effect of Palestinian Honey On Spermatogenesis in Rats. Jour Med Food 2008; 11 (4) 799-802.

5. Nworah DC, Chike CPR, Akpa MR, Nwafor A. Effects of Honey, Glutamine and Zinc On Male Sex Hormones and Semen Quality in Rats. AJOL 2012; 27 (2) 76-79.

6. Igbokwe VU, Gege-adebayo GI, Ogbadu S. Pure Honey a Potent Fertility Booster: Activities of Honey on Sperm Parameters in Adult Rats. IOSR Jour of Den Med Sci (IOSR-JDMS) 2013; 9 (6) 43-47.

7. Gheldof H, Engeseth NJ. Antioxidants Capacity of Honey from Various Floral Sources Based On the Determination of Oxygen Radical Absorbence Capacity and Inhibition of In-Vitro Lipoprotein Oxidation in Human 
Serum Samples. Jour Agric Food Chem 2002; 50 30503055.

8. Abdulsalam A, Ghailabil $D$, Rateb $M$, Rula $A$, Munir $Q$. Effect of Palestinian Honey, Glutamine and Zinc On Spermatogenesis in Rats. J Med Food 2008; 1 (4) 799802.

9. Dhawan K, Kumar S, Sharma A. beneficial effects of chrysin and benzoflavine on virility in 2-year-old male rat. J Med Food 2002; 5 (1) 43-8.

10. Ciftci O, Ozdemir I, Aydin M, Beytur A. Beneficial Effects of Chrysin on the Reproductive System of Adult Male Rats. Andrologia 2012; 44 (3) 181-186.

11. Kohut ML, Thompson JR, Campbell J, Brown GA, Vukovich MD, Jackson DA. Ingestion of a Dietary Supplement Containing Dehydroepiandrosterone (DHEA) and Androstenedione Has Minimal Effect On Immune Function in Middle Aged Man. J Am Coll Nutr 2003; 22 (5) 363-71.

12. Walle $T$, Otake $Y$, Gahjatovic A, Riller J, Walle UK. Induction of UDP-Glucuronosyltransferase UGT2A1 by the Flavonoid Chrysin in The Human Hepatoma Cell Line Hep G2. Drug and Metab 2015; 43 (10) 58-68.

13. Mayorga MP, Gromoll J, Behre HM, Gassner C, Nieschlag E, Simoni M. Ovarian Response to Follicle Stimulating Hormone (FSH). Stimulation Depends On The FSH Receptor Genotype. JCEM 2000; 85 (9) 33653369.

14. Saba $A B$, Oridupa $O A$, Oyeyemi $M O$, Osanyigbe $O D$. Spermatozoa morphology and characteristics of male Wistar rats administered with ethanolic extracts of Langenaria breviflora Roberts. Afri Jour Biotech 2009; 8 (7) $1170-1175$.

15. Oyeyemi MO, Ubiogoro $O$. Spermiogram and morphological characteristics in testicular and epididymal spermatozoa of Large White Boar in Nigeria. Int J Morphol 2005; 23 (3) 235-239.

16. Zemjanis $R$. Collection and evaluation of semen. In: Diagnostic. and Therapeutic Techniques in Animal
Reproduction. William and Wilkins company, Baltimore, USA 1977; p. 242

17. Pant N, Srivastava SP. Testicular and spermatotoxic effect of quinaphos in rats. J. Appl. Toxicol 2003; 23 271-274.

18. Wells ME, Awa OA. New technique for assessing acrosomal characteristics of spermatozoa. J. Diary Sci 1970; 53227.

19. Isaac AA, Ebenezer OF. Taurine enhances spermatogenic and antioxidant defence mechanisms in testis and epididymis of L-AAME induced hypertensive rats. Biomedicine \& Pharmacotherapy 2018; 97 181189.

20. Mahaneem M, Sitti Amrah MK, Hasnan J. Effect of Malaysian Honey On the Male Reproductive System in Rats. Malay Jour Med Sci 2007; 14114.

21. Yousef MI, Kamil KI, Mervat SH, Ahmed MAE. Protective Role of Propolis Against Reproductive Toxicity of Triphenyltin in Male Rabbits. Food Chem Toxicol 2009; 48 1846-1852.

22. Garner DL, Hafez ES. Spermatozoa and Seminal Plasma in Reproduction in arm Animals.7th ed. Lippincott Williams, 2000.

23. "Understanding Semen Analysis". Stonybrook, State University of New York. 1999. Archived from the original on October 17, 2007. Retrieved 2007-08-05.

24. Salman TM, Alagbonsi IA, Olayaki LA, Biliaminu $S A$, Salahdeen HM, Olowu OA. Honey increases sperm count in male albino rats by enhancing testosterone production. Biokemistri 2013; 25 (2) 39-44.

25. Frías I, Rubio C, González-Iglesias T, Gutiérrez AJ, González-Weller D, Hardisson A. "Metals in fresh honeys from Tenerife Island, Spain". Bull Environ Contam Toxicol 2008; 80 (1) 30-33.

26. Yamaguchia S, Miuraa C, Kikuchib K, Celinoa FT, Agusa $T$, Tanabec $S$ et al. Zinc is an essential trace element for spermatogenesis. Proc Nat Acad of Sci USA 2009; 106 (26) 10859-10864. 